\title{
Antidiabetic effect of Nigella sativa compared with metformin on blood glucose levels in streptozotocin induced diabetic albino wistar rats
}

\author{
Neeraj Sadiq ${ }^{1}$, Ghulam Subhani2*, Syeda Ayesha Fatima ${ }^{3}$, \\ M. Nadeem ${ }^{2}$, Shaima Zafer ${ }^{4}$, M. Mohsin ${ }^{2}$
}

\begin{abstract}
${ }^{1}$ Department of Pharmacology Kamineni institute of Medical Sciences, Narketpally, Telangana, India
${ }^{2}$ Department of Pharmacology, Deccan College of Medical Sciences, Hyderabad, Telangana, India

${ }^{3}$ Department of Pharmacology, Apollo institute of Medical Sciences, Jubilee Hills, Hyderabad, Telangana, India

${ }^{4}$ Darul Uloom University, Riyadh, Saudi Arabia
\end{abstract}

Received: 29 January 2021

Revised: 08 March 2021

Accepted: 09 March 2021

*Correspondence:

Dr. Ghulam Subhani,

Email: subhanis_2000@yahoo.com

Copyright: (c) the author(s), publisher and licensee Medip Academy. This is an open-access article distributed under the terms of the Creative Commons Attribution Non-Commercial License, which permits unrestricted non-commercial use, distribution, and reproduction in any medium, provided the original work is properly cited.

\begin{abstract}
Background: Antidiabetic drugs are many but all of them have adverse effects ranging from simple side effects to serious side effects like hypoglycemic coma. We need alternative drugs which will not only lower blood sugar level but have fewer side effects. One such daily use ingredient in our food is Nigella sativa (kalonji) which has many properties. Methods: This was an objective study in an experimental animal. We divided albino wistar rats into six groups each group with six rats. Diabetes was induced using drug streptozotocin. Three doses of Nigella sativa $0.5 \mathrm{ml}, 1 \mathrm{ml}, 1.5 \mathrm{ml}$ orally per rat were used. Metformin $(100 \mathrm{mg} / \mathrm{kg}$ body weight) was used as standard drug. Blood sugar was estimated using glucometer on day 0 (starting day of treatment), day 5, day 10, day 20, day 40. The effect of Nigella sativa was compared with metformin group using the Anova test. Statistical analysis was done using SPSS software version 20.

Results: Nigella sativa (NS) produced significant hypoglycemic effect. NS in the dose of $0.5 \mathrm{ml}, 1 \mathrm{ml}$ and $1.5 \mathrm{ml}$ produced significant reduction in blood glucose in comparison to day 0 . Metformin also (100 $\mathrm{mg} / \mathrm{kg}$ body weight) produced significant reduction in blood glucose on day 20 and day 40. Comparison of hypoglycemic effect of Nigella sativa is not significantly different on day $10(1 \mathrm{ml})$ and day $20(1.5 \mathrm{ml})$ in comparison to Metformin $(100 \mathrm{mg} / \mathrm{kg}$ body weight). Histopathological examination showed that there was partial regeneration of beta islet cells of pancreas by 1.5 $\mathrm{ml}$ of Nigella sativa which were damaged due to streptozotocin treatment.

Conclusions: Alternative method of treatment for diabetes is very much needed and the study shows the use of the spice (Nigella sativa) daily can lower the blood sugar levels and can serve as an alternative treatment of diabetes mellitus.
\end{abstract}

Keywords: Metformin, Nigella sativa, Streptozotocin

\section{INTRODUCTION}

Diabetes mellitus refers to a group of common metabolic disorders that share the common phenotype of hyperglycemia. ${ }^{1}$ Genetics and environmental factors are major reasons and their interactions lead to the development of diabetes. By the year 2025, it is estimated that the number of people affected will reach 300 million.
India is at the highest position if we take into consideration the developing economies. Also by the year 2025, a rise from 15 million to 60 million is projected An Indian statistical projection suggests that the number of diabetics will rise from 15 million in the year 1995 to 60 million in the year $2025 .^{2}$

According to WHO at least 347 million people worldwide were reported to suffer from diabetes or $9 \%$ of the 
population. Its incidence is increasing speedily, and it is calculable that by the year 2030, this number can nearly be double. WHO predicts that type 2 diabetes will be the seventh leading reason behind death in $2030 .{ }^{3}$ The long term complications associated with diabetes are major explanation for morbidity and mortality, imposing a high financial burden on health care prices. More than $80 \%$ of diabetes deaths occur in low and middle financial population of developing countries. ${ }^{4}$ The risk of heart disease and stroke increase with Diabetes. In an international study, $50 \%$ of people died of cardiovascular disease..$^{5}$

\section{History}

The term diabetes was coined by Aretaeus of Cappadocia which means "one that straddles". Diabetes was recorded in English, in the form diabete, in a medical text written around 1425. Sushruta in sixthcentury B.C.E identified diabetes and named it as Madhumeh. It was first recognized around 1500 B.C.E by the traditional Egyptians, who considered it as a rare condition within which a person had excessive urination and lost weight. The term diabetes mellitus, contemplate the fact that the urine of those affected had a sweet taste, was first used by the Greek physician Arataeus, who lived from about 80 to 138C.E. It was not until 1776, however, he actually measured the concentration of glucose in the urine of such patients and found it to be increased.

Although diabetes has been recognized but it was Joseph von Mering and Oskar Minkowski who in 1889 found that dogs whose pancreas was removed developed all the signs and symptoms of diabetes and died shortly afterwards. The endocrine role of the pancreas in metabolism was discovered in 1921 by Sir Fredrick Grant Banting and Charles Herbert Best. They went on to purify the hormone insulin from bovine pancreas at the University of Toronto. This lead to the availability of an effective treatmentinsulin injections and the first patient treated was in 1922. Many types of diabetes are recognized. ${ }^{6}$

\section{Drug review}

\section{Nigella sativa}

The scientific name derived from the Latin term Niger (black). In English, Nigella sativa seed is variously called kalonji (from Hindi), fennel flower, nutmeg flower, black caraway, and Roman coriander. Nigella sativa (NS) belongs to a family "Ranunculaeceae" is a spice which is well known for its medicinal properties and commonly known as black cumin. Nigella sativa is an annual flowering plant, native to south west Asia and cultivated in countries like middle eastern Mediterranean region, south Europe, Syria, Turkey, Saudi Arabia, Pakistan and India. ${ }^{7}$

Botanical information of Nigella sativa, Kingdom: Plantae, Division: Magnoliopsida. Order: Ranunculaeceae, Genus: Nigella Species: Nigella sativa.
It is a GMP product having the strength of $91 \mathrm{mg} / 100 \mathrm{ml}$ (Mohammadia products, Karimnagar). The seeds of this plant have been extensively used in the Unani system of medicine in the areas of external application and ingestion for diseases such as diabetes and kidney disease. Its use in folk medicine as a therapy for many diseases including diabetes mellitus, bronchial asthma, kidney and liver diseases. The seeds /oil have anti-inflammatory, analgesic, antipyretic, antiosteoporotic, antimicrobial and antineoplastic and also antidiabetic action. Nigella sativa also has antioxidant, lipid lowering activity, cardioprotective effect. $^{8}$ Seeds contain indazole ring bearing alkaloids such as nigellacine, nigellidine. Nigellimine and its N-oxides are of isoquinoline alkaloids. $^{8}$

\section{Chemical compositions}

The variation in nutrient composition of NS varieties from different origin is due to variation of cultivated region, storage condition and maturity stage.

Table 1: Chemical composition of Nigella sativa.

\begin{tabular}{|ll|}
\hline Composition & $\%$ \\
\hline Protein & 26.7 \\
\hline Fat & 28.5 \\
\hline Carbohydrates & 24.9 \\
\hline Crude fibre & 08.4 \\
\hline Ash & 4.8 \\
\hline
\end{tabular}

Fixed oil contains $22 \%$ monosaturated fatty acids and $50 \%$ polyunsaturated fatty acid and is also rich in linoleic acid and oleic acid. ${ }^{9}$

Most of the properties of whole seeds or their extract are mainly attributed to quinine constituents, of which thymoquinone (TQ) is the most abundant as well as the potent pharmacologically active compound which readily dimerise to form dithymoquinone. ${ }^{10,11}$

Potential adverse drug reactions: there is low level of toxicity. ${ }^{11}$

\section{Animal model for diabetes mellitus}

Animal experimentation has long history in the field of diabetes. Appropriate experimental animal models are essential tools for understanding the pathogenesis, complications, genetic, or environmental.

\section{Streptozotocin induced diabetes mellitus ${ }^{12}$}

Streptozotocin is a naturally occurring chemical which is particularly toxic to beta cells of pancreas.

Mechanism of action: It causes beta cell death 1) By process of methylation. 2) Free radical generation. 3) Nitric acid production 


\section{METHODS}

The study was carried out in the postgraduate research laboratory of the Department of Pharmacology, Deccan College of Medical Sciences Hyderabad, after obtaining permission from the institutional Animal Ethics committee (IAEC). Laboratory bred albino wistar rats of male sex were obtained from central animal house of the institute. It was an objective experimental animal study carried out from January 2016 to March 2016. The material required for the present study was as follows: Animals- laboratory bred male albino wistar rats 30 in number. Weight of rats was $150-200 \mathrm{gm}$.

\section{Instruments}

1) Glucometer and strips (one touch Horizon, life Scan, Scotland Ltd., UK). 2) Oral feeding tubes, disposable tuberculin syringes. 3) Drugs: i) Streptozotocin (Hi media labs, Mumbai). ii) Nigella sativa oil (Mohammadia products, Karimnagar): It is a GMP product having the strength of $91 \mathrm{mg} / 100 \mathrm{ml}$. iii) Metformin ( $100 \mathrm{mg} / \mathrm{kg}$ body weight standard drug powder dissolved in distilled water).

\section{Animals}

Laboratory bred male albino wistar rats weighing 200-220 gm were used for the study. They were fed with standard diet and water ad libitum. They were acclimatized with the laboratory conditions before carrying out the experimental work.

\section{Instruments}

Glucometer: One touch horizon brand was used. It is manufactured by Life Scan Scotland Ltd. UK. It is an instrument used to check blood glucose levels. It is easy to use, quick to perform and reliable. The test strip is inserted into the glucometer, the tail vein of the rat is pricked with a sterile lancet and the blood sample is directly placed on the test strip. The result i.e. the blood glucose level will appear on the screen within five seconds in $\mathrm{mg} / \mathrm{dl}$.

Oral feeding tubes: size number 5 was used. It is manufactured by Royal Surgicare Pvt. Ltd. They were used to administer Nigella sativa oil and metformin orally.

Tuberculin syringes: the tuberculin syringes (of divisions $1 \mathrm{ml}=100$ units was used for administration of STZ intraperitoneally.

\section{Inclusion criteria}

After 48 hours of induction using STZ, the rats having blood glucose level more than $200 \mathrm{mg} \%$ were included in the study.

The rats were divided into five groups each group had six rats. Group 1 diabetic control 6 rats induced with Streptozotocin. Group 2 standard drug metformin PC (positive control) 6 rats. Group 3 Nigella sativa $0.5 \mathrm{ml}$ was fed in 6 rats. Group 4 Nigella sativa $1 \mathrm{ml}$ fed in 6 rats. Group 5 Nigella sativa $1.5 \mathrm{ml}$ fed in 6 rats.

Rats were given 15 days acclimatization to day and night cycle. Prior to the actual study, a pilot study was done in albino rats to estimate the probable diabetes producing dose of streptozotocin. It was done using minimal doses and the effective dose was established as $30 \mathrm{mg} / \mathrm{kg}$ body weight. ${ }^{13}$ After 48 hours of STZ injection and overnight fast, the blood was drawn from the tail vein of the rat. The drug was fed to the rats daily and the fasting blood sugar level was recorded on day $0,5,10,20,40^{\text {th }}$ day.

\section{RESULTS}

Streptozotocin (30 $\mathrm{mg} / \mathrm{kg}$ body weight IP) was used to induce diabetes mellitus in albino rats, only those rats which showed $200 \mathrm{mg} / 100 \mathrm{ml}$ blood glucose levels with glucometer method after 48 hours of streptozotocin were considered as diabetic animals.

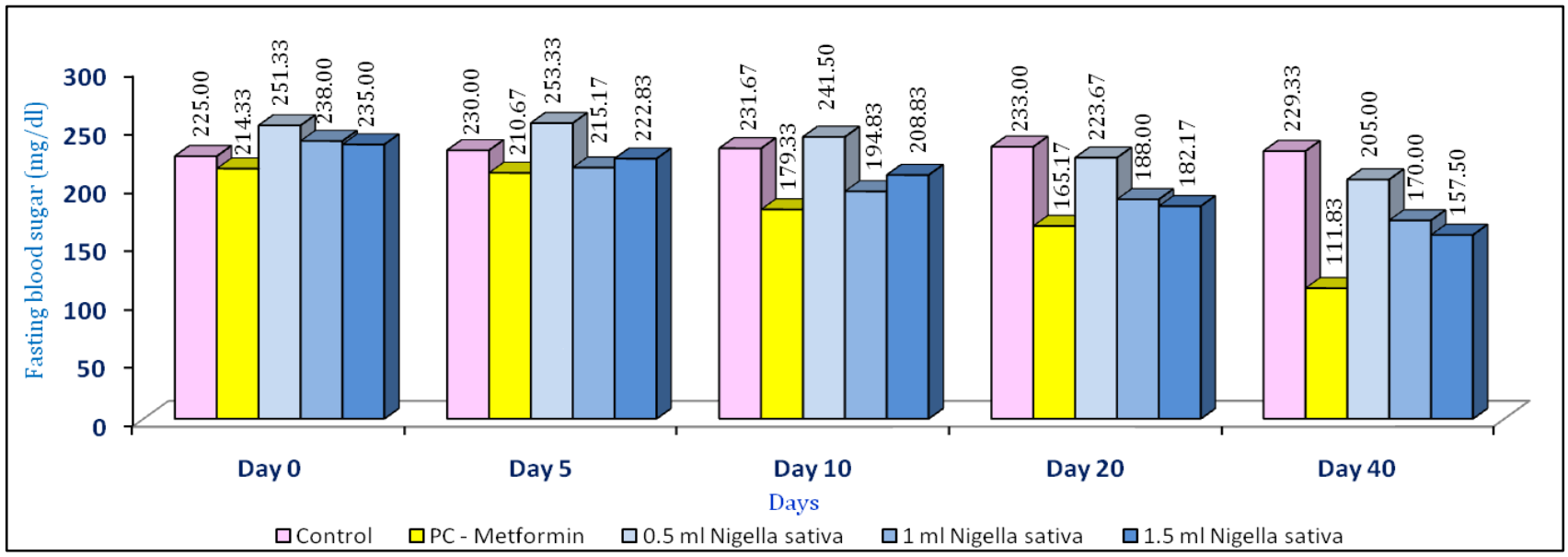

Figure 1: The blood glucose level on day $0,5,10,20,40$ of treatment with control, PC metformin, NS $(0.5 \mathrm{ml}, 1 \mathrm{ml}$, $1.5 \mathrm{ml}$ ) in strptozotocin induced diabetic rats. 
Metformin $100 \mathrm{mg} / \mathrm{kg}$ body weight PC (positive control), NS $0.5 \mathrm{ml}, 1 \mathrm{ml}, 1.5 \mathrm{ml}$ per rat was administered orally on day 0 of diabetic rats and treatment continued daily up to 40 days and blood glucose levels were estimated on day 5 , 10, 20 and 40 days of treatment.

In comparison to control group, blood glucose levels were reduced significantly in metformin PC group (day 20 and day40), Nigella sativa $0.5 \mathrm{ml}$ (day 20), Nigella sativa $1 \mathrm{ml}$ (day 5, day 10, day 20 and day 40) and Nigella sativa 1.5 $\mathrm{ml}$ (day 10 and day 40) (Table 2 and Figure 1).
The onset of significant antidiabetic effect in NS $1 \mathrm{ml}$ (day 5), $1.5 \mathrm{ml}$ (day 10) was rapid than metformin group (day 20) (Table 2 and Figure 1).

The blood sugar lowering effect of Nigella sativa $0.5 \mathrm{ml}, 1$ $\mathrm{ml}, 1.5 \mathrm{ml}$ was compared with metformin PC groups on day 5 , day 10 , day 20 , day 40 (Table 3). On day 5 the blood sugar lowering effect of Nigella sativa $0.5 \mathrm{ml}$ and $1 \mathrm{ml}$ was statistically non -significant compared to metformin group.

Table 2: Effect of metformin (positive control-PC), and NS ( $0.5 \mathrm{ml}, 1 \mathrm{ml}, 1.5 \mathrm{ml})$ pretreatment on blood glucose levels (mean+SD) on day 0 , day 5 , day 10 , day 20 , day 40 with control group) in streptozotocin treated rats.

\begin{tabular}{|c|c|c|c|c|c|}
\hline Group & Days & Mean \pm SD & Mean difference & Multiple comparisons (p value) & (F and p value) \\
\hline \multirow{5}{*}{ Control } & Day 0 & $225.00 \pm 11.83$ & - & - & \multirow{5}{*}{$\begin{array}{l}(22.41, \\
\mathrm{p}<0.0001)^{*}\end{array}$} \\
\hline & Day 5 & $230.00 \pm 11.83$ & -5.00 & $\mathrm{P}>0.05(\mathrm{NS})$ & \\
\hline & Day 10 & $231.67 \pm 8.45$ & -6.68 & $\mathrm{P}<0.05(\mathrm{~S})$ & \\
\hline & Day 20 & $233.00 \pm 5.93$ & -8.00 & $\mathrm{P}>0.05(\mathrm{NS})$ & \\
\hline & Day 40 & $229.33 \pm 5.89$ & -4.33 & $\mathrm{P}>0.05(\mathrm{NS})$ & \\
\hline \multirow{5}{*}{$\begin{array}{l}\mathrm{PC}- \\
\text { metformin }\end{array}$} & Day 0 & $214.33 \pm 4.27$ & - & - & \multirow{5}{*}{$\begin{array}{l}(4.56, \\
\mathrm{p}=0.0061)^{*}\end{array}$} \\
\hline & Day 5 & $210.67 \pm 30.00$ & 3.68 & $\mathrm{P}>0.05(\mathrm{NS})$ & \\
\hline & Day 10 & $179.33 \pm 24.35$ & 35.00 & $\mathrm{P}>0.05(\mathrm{NS})$ & \\
\hline & Day 20 & $165.17 \pm 32.60$ & 49.17 & $\mathrm{P}<0.05(\mathrm{~S})$ & \\
\hline & Day 40 & $111.83 \pm 7.22$ & 102.50 & $\mathrm{P}<0.0001(\mathrm{~S})$ & \\
\hline \multirow{5}{*}{$\begin{array}{l}0.5 \mathrm{ml} \\
\text { Nigella } \\
\text { sativa }\end{array}$} & Day 0 & $251.33 \pm 13.55$ & - & - & \multirow{5}{*}{$\begin{array}{l}(4.26 \\
\mathrm{p}=0.0085)^{*}\end{array}$} \\
\hline & Day 5 & $253.33 \pm 13.14$ & -2.00 & $\mathrm{P}>0.05(\mathrm{NS})$ & \\
\hline & Day 10 & $241.50 \pm 16.54$ & 9.83 & $\mathrm{P}>0.05(\mathrm{NS})$ & \\
\hline & Day 20 & $223.67 \pm 11.45$ & 27.67 & $\mathrm{P}<0.01(\mathrm{~S})$ & \\
\hline & Day 40 & $205.00 \pm 4.60$ & 46.33 & $\mathrm{P}<0.001(\mathrm{~S})$ & \\
\hline \multirow{5}{*}{$\begin{array}{l}1 \mathrm{ml} \\
\text { Nigella } \\
\text { sativa }\end{array}$} & Day 0 & $238.00 \pm 7.54$ & - & - & \multirow{5}{*}{$\begin{array}{l}(4.97 \\
\mathrm{p}=0.0040)^{*}\end{array}$} \\
\hline & Day 5 & $215.17 \pm 13.20$ & 22.83 & $\mathrm{P}<0.001(\mathrm{~S})$ & \\
\hline & Day 10 & $194.83 \pm 6.80$ & 43.17 & $\mathrm{P}<0.0001(\mathrm{~S})$ & \\
\hline & Day 20 & $188.00 \pm 9.42$ & 50.00 & $\mathrm{P}<0.0001(\mathrm{~S})$ & \\
\hline & Day 40 & $170.00 \pm 1.55$ & 68.00 & $\mathrm{P}<0.00001(\mathrm{~S})$ & \\
\hline \multirow{5}{*}{$\begin{array}{l}1.5 \mathrm{ml} \\
\text { Nigella } \\
\text { sativa }\end{array}$} & Day 0 & $235.00 \pm 12.22$ & - & - & \multirow{5}{*}{$\begin{array}{l}(5.24, \\
\mathrm{p}=0.0031)^{*}\end{array}$} \\
\hline & Day 5 & $222.83 \pm 11.39$ & 12.17 & $\mathrm{P}>0.05(\mathrm{NS})$ & \\
\hline & Day 10 & $208.83 \pm 15.21$ & 26.17 & $\mathrm{P}<0.01(\mathrm{~S})$ & \\
\hline & Day 20 & $182.17 \pm 13.01$ & 52.83 & $\mathrm{P}<0.001(\mathrm{~S})$ & \\
\hline & Day 40 & $157.50 \pm 5.82$ & 77.50 & $\mathrm{P}<0.001(\mathrm{~S})$ & \\
\hline
\end{tabular}

Note: S: Significant, NS: Non-Significant

Table 3: Comparison of metformin PC group and NS $(0.5 \mathrm{ml}, 1 \mathrm{ml}, 1.5 \mathrm{ml})$ groups on blood glucose levels at 5 , 10 , 20 and 40 days treatment in streptozotocin treated animals.

\begin{tabular}{|c|c|c|c|c|c|}
\hline Days & Group & Mean \pm SD & Mean difference & Multiple comparisons (p value) & ( $F$ and $p$ value)\# \\
\hline \multirow{5}{*}{$\begin{array}{l}\text { Day } \\
0\end{array}$} & PC- metformin & $214.33 \pm 4.27$ & - & - & \multirow{5}{*}{$\begin{array}{l}(135.48 \\
\mathrm{p}<0.05)\end{array}$} \\
\hline & Control & $225.00 \pm 11.83$ & 10.67 & $0.0900(\mathrm{NS})$ & \\
\hline & $0.5 \mathrm{ml}$ Nigella sativa & $251.33 \pm 13.55$ & $-37.000 *$ & $0.0000(\mathrm{~S})$ & \\
\hline & $1 \mathrm{ml}$ Nigella sativa & $238.00 \pm 7.54$ & $-23.667 *$ & $0.0001(\mathrm{~S})$ & \\
\hline & $1.5 \mathrm{ml}$ Nigella sativa & $235.00 \pm 12.22$ & $-20.667 *$ & $0.0006(\mathrm{~S})$ & \\
\hline \multirow{4}{*}{$\begin{array}{l}\text { Day } \\
5\end{array}$} & PC- metformin & $210.67 \pm 30.00$ & - & - & \multirow{4}{*}{$(63.99, \mathrm{p}<0.05)$} \\
\hline & Control & $230.00 \pm 11.83$ & 19.333 & $0.0660(\mathrm{NS})$ & \\
\hline & $0.5 \mathrm{ml}$ Nigella sativa & $253.33 \pm 13.14$ & $-42.667 *$ & $0.0002(\mathrm{~S})$ & \\
\hline & $1 \mathrm{ml}$ Nigella sativa & $215.17 \pm 13.20$ & -4.50 & $0.6431(\mathrm{NS})$ & \\
\hline
\end{tabular}




\begin{tabular}{|c|c|c|c|c|c|}
\hline Days & Group & Mean \pm SD & Mean difference & Multiple comparisons ( $\mathrm{p}$ value) & (F and $p$ value)\# \\
\hline & $1.5 \mathrm{ml}$ Nigella sativa & $222.83 \pm 11.39$ & -12.17 & 0.2165 (NS) & \\
\hline \multirow{5}{*}{$\begin{array}{l}\text { Day } \\
10\end{array}$} & PC- metformin & $179.33 \pm 24.35$ & - & - & \multirow{5}{*}{$(97.37, \mathrm{p}<0.05)$} \\
\hline & Control & $231.67 \pm 8.45$ & $-52.333^{*}$ & $0.0000(\mathrm{~S})$ & \\
\hline & $0.5 \mathrm{ml}$ Nigella sativa & $241.50 \pm 16.54$ & $-62.167 *$ & $0.0000(\mathrm{~S})$ & \\
\hline & $1 \mathrm{ml}$ Nigella sativa & $194.83 \pm 6.80$ & -15.50 & $0.0887(\mathrm{NS})$ & \\
\hline & $1.5 \mathrm{ml}$ Nigella sativa & $208.83 \pm 15.21$ & $-29.500 *$ & $0.0024(\mathrm{~S})$ & \\
\hline \multirow{5}{*}{$\begin{array}{l}\text { Day } \\
20\end{array}$} & PC- metformin & $165.17 \pm 32.60$ & - & - & \multirow{5}{*}{$\begin{array}{l}(103.49, \\
\mathrm{p}<0.05)\end{array}$} \\
\hline & Control & $233.00 \pm 5.93$ & $-67.833^{*}$ & $0.0000(\mathrm{~S})$ & \\
\hline & $0.5 \mathrm{ml}$ Nigella sativa & $223.67 \pm 11.45$ & $-58.500 *$ & $0.0000(\mathrm{~S})$ & \\
\hline & $1 \mathrm{ml}$ Nigella sativa & $188.00 \pm 9.42$ & $-22.833^{*}$ & $0.0290(\mathrm{~S})$ & \\
\hline & $1.5 \mathrm{ml}$ Nigella sativa & $182.17 \pm 13.01$ & -17.00 & 0.0970 (NS) & \\
\hline \multirow{5}{*}{$\begin{array}{l}\text { Day } \\
\mathbf{4 0}\end{array}$} & PC- metformin & $111.83 \pm 7.22$ & - & - & \multirow{5}{*}{$\begin{array}{l}(1934.63 \\
p<0.05)\end{array}$} \\
\hline & Control & $229.33 \pm 5.89$ & $-117.500^{*}$ & $0.0000(\mathrm{~S})$ & \\
\hline & $0.5 \mathrm{ml}$ Nigella sativa & $205.00 \pm 4.60$ & $-93.167 *$ & $0.0000(\mathrm{~S})$ & \\
\hline & $1 \mathrm{ml}$ Nigella sativa & $170.00 \pm 1.55$ & $-58.167 *$ & $0.0000(\mathrm{~S})$ & \\
\hline & $1.5 \mathrm{ml}$ Nigella sativa & $157.50 \pm 5.82$ & $-45.667^{*}$ & $0.0000(\mathrm{~S})$ & \\
\hline
\end{tabular}

Note: $* \mathrm{P}<0.05$ level of significant, S: Significant, NS: Non-Significant

\#Mean fasting blood sugar values are statistically different from Metformin using ANOVA one way analysis test.

On day 10 the blood sugar lowering effect of Nigella sativa $1 \mathrm{ml}$ was statistically non-significant in comparison to metformin group. On day 20 the blood sugar lowering effect of Nigella sativa $1.5 \mathrm{ml}$ was statistically nonsignificant in comparison to Metformin group. All these three findings suggest blood sugar lowering effect of Nigella sativa $(0.5 \mathrm{ml}, 1 \mathrm{ml}$ and $1.5 \mathrm{ml})$ was comparable with metformin ( $200 \mathrm{mg} / \mathrm{kg}$ body weight) at either day 5/day 10/day 20 .

Histopathological examination showed that there was partial regeneration of beta islet cells of pancreas by $1.5 \mathrm{ml}$ of Nigella sativa which were damaged due to Streptozotocin treatment (Figure 2a, b, c).

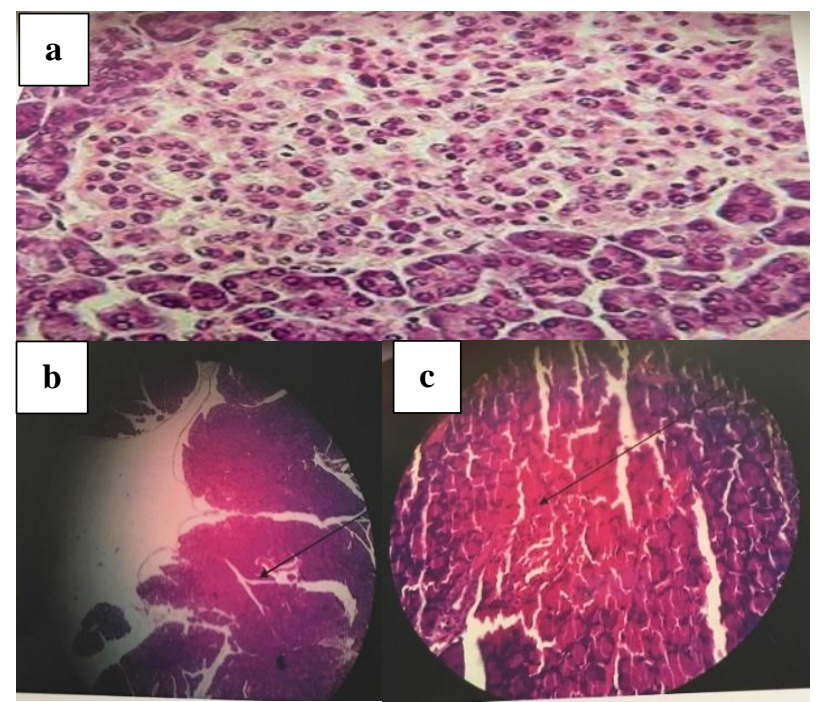

Figure 2: (a) HPE of normal pancreas; (b) HPE of streptozotocin induced diabetic pancreas; (c) HPE of Nigella sativa treated diabetic pancreas.

\section{DISCUSSION}

The seeds of this plant under study Nigella sativa have been extensively been used in the Unani system of medicine ranging from external application to ingestion for diseases such as diabetes and kidney diseases. Hence the present study is conducted to evaluate the effect of Nigella sativa oil on the blood glucose levels of streptozotocin induced diabetic albino rats. ${ }^{14}$

Zaowi and Cherrah showed that 12 weeks of daily treatment with Nigella sativa lowers glucose levels significantly also our results are in consistent with the findings of Huda Kaatabi and Abdulla Bamosa which showed that Nigella sativa improves glucose homeostasis and enhances antioxidant defence system in type 2 diabetic patients. ${ }^{15,16}$

In a systematic analysis Daryabeygi et al found Nigella sativa significantly improved fasting blood sugar levels with lowering of lipid levels also. ${ }^{17}$

Moreover the hypoglycemic effect of Nigella sativa may be due to enhancement of beta cell ultrastructure thus leading to increased insulin levels, as a result Nigella sativa and thymoquinone may prove helpful in the treatment of type II diabetes patients. ${ }^{18}$

Although in another study by Rashidmayvan et al insulin levels did not decrease but fasting blood sugar levels decreased significantly and other markers also became low like liver enzymes, lipid profile, inflammatory markers. ${ }^{19}$

In another study by Hawasi et al also reported significant hypoglycemic effect of Nigella sativa in 2001 in Albino rats. The possible mechanism of antidiabetic effect of Nigella sativa might be due to regenerative effect of 
Nigella sativa on the streptozotocin damaged beta cells as observed in our present study (Figure 2). ${ }^{20,21}$

Nigella sativa produced significant reduction in blood glucose in all the three doses $(0.5 \mathrm{ml}, 1 \mathrm{ml}, 1.5 \mathrm{ml})$ on day $5(1 \mathrm{ml})$, day $10(1 \mathrm{ml}$ and $1.5 \mathrm{ml})$ day $20(0.5 \mathrm{ml}, 1 \mathrm{ml}, 1.5$ $\mathrm{ml})$ and day $40(0.5 \mathrm{ml}$ and $1 \mathrm{ml}$ and $1.5 \mathrm{ml})$ in comparison to day 0 suggesting Nigella sativa has significant antidiabetic effect (Table 2 Figure 1). The metformin PC (200 mg/kg body weight) also produced significant sugar lowering effect on day 20 and day 40 only in comparison to day 0 .

The efficacy of NS might be comparable to the metformin as observed in the present study- (a) The blood sugar lowering effect of Nigella sativa $0.5 \mathrm{ml}, 1 \mathrm{ml}, 1.5 \mathrm{ml}$ was compared with metformin PC groups on day 5, day 10 , day 20, day 40 (Table 3). On day 5 the blood sugar lowering effect of Nigella sativa $0.5 \mathrm{ml}$ and $1 \mathrm{ml}$ was statistically non-significant compared to metformin group. (b) On day 10 the blood sugar lowering effect of Nigella sativa $1 \mathrm{ml}$ was statistically non-significant in comparison to metformin group. (c) On day 20 the blood sugar lowering effect of Nigella sativa $1.5 \mathrm{ml}$ was statistically nonsignificant in comparison to metformin group. All these three findings suggest blood sugar lowering effect of Nigella sativa $(0.5 \mathrm{ml}, 1 \mathrm{ml}$ and $1.5 \mathrm{ml})$ is comparable with metformin (200 mg/kg body weight) at either day 5/day $10 /$ day 20.

\section{CONCLUSION}

Nigella sativa is used in folk medicine as a therapy for many diseases including diabetes mellitus, bronchial asthma, kidney and liver diseases. Hence the present study was undertaken to evaluate the effect of Nigella sativa oil on the blood glucose levels in streptozotocin induced diabetic rats. NS oil in the doses $0.5 \mathrm{ml}, 1 \mathrm{ml}$, and $1.5 \mathrm{ml}$ orally per rat produced significant lowering of blood glucose on day $5(1 \mathrm{ml}) /$ day $10(1 \mathrm{ml}$ and $1.5 \mathrm{ml}) /$ day 20 $(0.5 \mathrm{ml}, 1 \mathrm{ml}, 1.5 \mathrm{ml})$ and day $40(1 \mathrm{ml}$ and $1.5 \mathrm{ml})$. The standard drug metformin (200 $\mathrm{mg} / \mathrm{kg}$ body weight) also significantly lowered the blood glucose on day 20 and day 40 further antidiabetic effect of all the three doses of NS is comparable with metformin.

The antidiabetic effect of NS may be due to regenerating potentiality because in the present study it is observed NS treatment $(1.5 \mathrm{ml})$ caused regeneration of beta cells of pancreas in the streptozotocin induced diabetic rats.

\section{ACKNOWLEDGEMENTS}

Authors would like to thank Department of Pharmacology DCMS.

\author{
Funding: No funding sources \\ Conflict of interest: None declared \\ Ethical approval: The study was approved by the \\ Institutional Ethics Committee
}

\section{REFERENCES}

1. Powers AC. Diabetes Mellitus. In: Longo DL, Fauci AS, Kasper DL, Hauser SL, Jameson JL, Loscalzo J, eds. Harrison's Principles of Internal Medicine. 18th Ed. Vol- 2. USA: McGraw-Hill; 2012:2968-3009.

2. Mendis S, Davis S, Norrving B. Organizational update: the world health organization global status report on noncommunicable diseases 2014; one more landmark step in the combat against stroke and vascular disease. Stroke. 2015;46(5):e121-e122.

3. Mathers CD, Loncar D. Projections of global mortality and burden of disease from 2002 to 2030 . PLoS Med. 2006;3(11):e442.

4. World Health Organization. Global Health Estimates: Deaths by cause, age, sex and country, 2000-2015. Geneva: WHO; 2014.

5. Morrish NJ, Wang SL, Stevens LK, Fuller JH, Keen H. Mortality and causes of death in the WHO multinational study of vascular disease in diabetes. Diabetologia. 2001;44(2):S14-21.

6. Laios K, Karamanou M, Saridaki Z, Androutsos G. Aretaeus of Cappadocia and the first description of diabetes. Hormones. 2012;11(1):109-13.

7. Abel-Salam BK. Immunomodulatory effects of black seeds and garlic on alloxan-induced diabetes in albino rat. Allergol Immunopathol. 2012;40(6):336-40.

8. Assi MA, Noor MM, Bachek NF, Ahmad H, Haron AW, Yusoff MSM, et al . The various effects of Nigella sativa on multiple body systems in human and animals. Pertanika J Schol Res Rev. 2016;2(3):1-19.

9. Mehta BK, Pandit V, Gupta M. New principles from seeds of Nigella sativa. Nat Prod Res. 2009;23(2):13848.

10. Khan MA. Chemical composition and medicinal properties of Nigella sativa Linn. Inflammopharmacology. 1999;7(1):15-35.

11. Ahmad A, Husain A, Mujeeb M, Khan SA, Najmi AK, Siddique NA, et al. A review on therapeutic potential of Nigella sativa: A miracle herb. Asian Pac J Trop Biomed. 2013;3(5):337-52.

12. Furman BL. Streptozotocin-Induced diabetic models in mice and rats. Curr Protoc Pharmacol. 2015;70:547.

13. King AJ. The use of animal models in diabetes research. Br J Pharmacol. 2012;166(3):877-94.

14. Desveaux L. Exercise and disease management. Physiother Can. 2013;65(2):195.

15. Zaoui A, Cherrah Y, Alaoui K, Mahassine N, Amarouch H, Hassar M. Effects of Nigella sativa fixed oil on blood homeostasis in rat. J Ethnopharmacol. 2002;79(1):23-6.

16. Kaatabi H, Bamosa AO, Badar A, Al-Elq A, AbouHozaifa B, Lebda F, et al. Nigella sativa improves glycemic control and ameliorates oxidative stress in patients with type 2 diabetes mellitus: placebo controlled participant blinded clinical trial. PloS One. 2015;10(2):e0113486.

17. Daryabeygi-Khotbehsara R, Golzarand M, Ghaffari MP, Djafarian K. Nigella sativa improves glucose 
homeostasis and serum lipids in type 2 diabetes: a systematic review and meta-analysis. Complement Ther Med. 2017;35:6-13.

18. Abdelmeguid NE, Fakhoury R, Kamal SM, Al Wafai RJ. Effects of Nigella sativa and thymoquinone on biochemical and subcellular changes in pancreatic $\beta$ cells of streptozotocin-induced diabetic rats. J Diabetes. 2010;2(4):256-66.

19. Rashidmayvan M, Seyedian SS, Haghighizadeh MH. The effect of Nigella sativa oil on serum levels of inflammatory markers, liver enzymes, lipid profile,insulin and fasting blood sugar in patients with non-alcoholic fatty liver. J Diabetes Metab Disord. 2019;18(2):453-9.

20. Bamosa AO, Kaatabi H, Lebdaa FM, Elq AM, AlSultanb A. Effect of Nigella sativa seeds on the glycemic control of patients with type 2 diabetes mellitus. Indian J Physiol Pharmacol. 2010;54(4):344-54.

21. Alimohammadi S, Hobbenaghi R, Javanbakht J, Kheradmand D, Mortezaee R, Tavakoli M, et al. Retraction note: protective and antidiabetic effects of extract from Nigella sativa on blood glucose concentrations against streptozotocin (STZ)-induced diabetic in rats: an experimental study with histopathological evaluation. Diagn Pathol. 2016;11(1):125.

Cite this article as: Sadiq N, Subhani G, Fatima SA, Nadeem M, Zafer S, Mohsin M. Antidiabetic effect of Nigella sativa compared with metformin on blood glucose levels in streptozotocin induced diabetic albino wistar rats. Int $\mathrm{J}$ Basic Clin Pharmacol 2021;10:361-7. 